\title{
Development of an efficient protocol for high-frequency regeneration system in Hibiscus syriacus $\mathbf{L}$.
}

\author{
Sang-Gyu Seo $\cdot$ Sun-Hee Ryu $\cdot$ Yang Zhou $\cdot$ Sun-Hyung Kim \\ Received: 21 June 2017 / Revised: 21 June 2017 / Accepted: 21 June 2017 \\ (C) Korean Society for Plant Biotechnology
}

\begin{abstract}
A rapid and efficient in vitro regeneration system was established for Hibiscus syriacus L. The successful regeneration protocol employs induction of shoot organogenesis on leaf, petiole, and root explants. Among the various plant growth regulators evaluated, thidiazuron (TDZ) was the most effective for inducing rapid shoot formation. Most efficient shoot regeneration frequency was obtained from Murashige and Skoog (MS) media containing $0.01 \mathrm{mg} / \mathrm{L}$ TDZ. Regeneration efficiency was highest in the roots, and lowest in the leaves. A combination of $0.01 \mathrm{mg} / \mathrm{L} \mathrm{TDZ}$ with benzyladenine (BAP) markedly improved the frequency of shoot differentiation from the root (up to 98\%) and petiole (up to 88\%) explants. Furthermore, leaf and petiole explants showed the highest frequency of shoot induction in half-strength MS media containing $0.01 \mathrm{mg} / \mathrm{L} \mathrm{TDZ}$ and $1.0 \mathrm{mg} / \mathrm{L} \mathrm{BAP}$, while root explants formed the greatest number of shoots when 0.01 $\mathrm{mg} / \mathrm{L}$ TDZ and $0.1 \mathrm{mg} / \mathrm{L}$ BAP were added to half-strength MS media. Although the frequency of shoot differentiation from leaf explants was only $50 \%$, the leaf is considered the most efficient plant organ for use in tissue culture because leaves are easier to obtain than roots and petioles. Our findings show that various organs of $H$. syriacus can be used for plant regeneration, and the protocol developed in this study may be applicable in the horticulture industry.
\end{abstract}

Keywords Hibiscus syriacus L. leaf explant, petiole explant, root explant, shoot differentiation, thidiazuron

S.-G. Seo · S.-H. Ryu $\cdot$ Y. Zhou $\cdot$ S.-H. Kim $(\bowtie)$

Department of Environmental Horticulture, The University of Seoul, Seoulsiripdae-ro 163, Dongdaemun-gu, Seoul, 130-743, Republic of Korea

e-mail: kimmads3327@gmail.com

\section{Introduction}

Hibiscus syriacus L., the national flower of Korea, is a common ornamental plant found in gardens and parks and along roadsides in Korea. It also has various economically important uses such as in the production of fiber and as a beverage additive in some Asian countries (Hotta et al. 1989). H. syriacus is commonly propagated using cuttings (Govinden-Soulange et al. 2009), which offer several advantages, such as the regeneration of clones, convenience of propagation, combination of genotypes, and reduction in length of the juvenile period (Hartman et al. 1994). However, this method is slow, requires considerable space, and relies on cuttings from mother plants. Propagation through seeds is not a viable option, as the germination percentage is low and seed-propagated plants may display undesirable traits and lack uniformity. Thus, this commercially valuable species may benefit from the development of an efficient and low-cost protocol for large-scale in vitro multiplication. Previous studies explored the propagation of $H$. syriacus through plant regeneration using shoot tips (Kim et al. 1998; Jeon et al. 2009; Yoo et al. 1996), embryos (Peak et al. 1989), and protoplasts (Zhao et al. 1991). However, regeneration efficiency is low and it is difficult to apply these methods in mass proliferation of $H$. syriacus. The application of tissue culture is sometimes limited by the quality and availability of the various plant materials needed to initiate the culture. Therefore, certain plant parts, such as leaves, petioles, and roots, which are more abundant and easier to procure than shoot tips, show potential for use in tissue culture. The objective of this study was to develop an efficient method of plant regeneration for $H$. syriacus using leaves, petioles, and roots and develop an efficient protocol for mass multiplication of $H$. syriacus. 


\section{Materials and Methods}

Explant Source, Basal Medium Composition, and Experimental Conditions

In vitro plants of $H$. syriacus 'Saimdang' were used as the source of plant materials for this study. Fresh leaves, petioles, and roots cut from in vitro plants were sterilized in $70 \%$ ethanol for $30 \mathrm{~s}$ and washed in sterile distilled water. Next, the samples were sterilized in 1\% sodium hypochlorite for $1 \mathrm{~min}$ and rinsed five times with sterile distilled water. Leaf explants were obtained by excising approximately $0.5 \times 0.5-\mathrm{cm}$ pieces from sterilized leaves and petiole and root explants were obtained by cutting 0.5 -cm-long segments from sterilized petioles and roots. The explants were then placed in MS medium.

Induction of In Vitro Shoot Morphogenesis

MS basal medium (Murashige and Skoog 1962), containing $30 \mathrm{~g} / \mathrm{L}$ sucrose and $3 \mathrm{~g} / \mathrm{L}$ gelrite, was used for all tissue culture media. The $\mathrm{pH}$ of the medium was adjusted to 5.8 before autoclaving at $120^{\circ} \mathrm{C}$ for $10 \mathrm{~min}$. Each explant was cultured on MS medium containing either various concentrations of the growth regulator thidiazuron (TDZ; 0.001, $0.01,0.5,1.0$, and $2.0 \mathrm{mg} / \mathrm{L}$ ) alone or in combination with various concentrations of benzyladenine (BAP; 0.1, 0.5, and $1.0 \mathrm{mg} / \mathrm{L}$ ) or naphthaleneacetic acid (NAA; 0.5 and $1.0 \mathrm{mg} / \mathrm{L}$ ) in a dark room at a temperature of $25 \pm 1^{\circ} \mathrm{C}$ for 3 weeks. The culture plates were then subjected to a $16-\mathrm{h} / 8$-h photoperiod at room temperature $\left(25 \pm 1^{\circ} \mathrm{C}\right)$. Subculture was carried out every 4 weeks. After 7 weeks of culture, the frequency of callus induction and shoot formation was measured.

\section{In Vitro Rooting of Regenerated Shoots}

Shoots cut from plantlets cultured on the shooting medium were transferred and cultured on a rooting medium consisting of half-strength MS basal medium supplemented with various concentrations $(0.01,0.1,0.5,1.0$, and $1.5 \mathrm{mg} / \mathrm{L})$ of indole-3-acetic acid (IAA). Culture was conducted at room temperature under a $16-\mathrm{h} / 8-\mathrm{h}$ photoperiod. The number of days required for root emergence to occur was measured for each rooting shoot. Each experiment was repeated three times.

\section{Results and Discussion}

Effects of Explant Source and TDZ Concentration on In Vitro Regeneration

H. syriacus is generally propagated using leaf or stem cuttings. However, this method is slow, requires considerable space, and relies on cuttings from mother plants. In vitro multiplication techniques are now effectively employed for the mass clonal multiplication of commercially important plant species, such as Saintpaulia ionantha (Lo et al. 1997; Mithila et al. 2003), Titonotrichum oldhamii (Takagi et al. 2011) and Aeschynanthus radicans (Cui et al. 2009). The goal of the present study was to develop a simple and efficient propagation protocol for rapid in vitro multiplication of $H$. syriacus utilizing TDZ, a potent plant growth regulator (PGR) known to induce shoot morphogenesis and somatic embryogenesis (SE) in vitro. In vitro regeneration was achieved successfully through either SE or shoot organogenesis in H. syriacus by using different explants cultured on a range of PGRs, alone or in combination. Shoot organogenesis and SE modulated by TDZ are well-documented in many plant species (Hutchinson et al. 1996; Murthy et al. 1998; Murch and Saxena 2001; Jones et al. 2007). TDZ used alone at low concentrations induced shoot organogenesis and at high concentrations induced in African violet (S.ionantha) (Mithila et al. 2003; Taha et al. 2009) and Ochna integerrima (Ma et al. 2011). Preliminary tests revealed that calluses were not formed when explants were cultured on MS medium containing either 2.0 or $5.0 \mathrm{mg} / \mathrm{L}$ 2,4-D (data not shown), whereas all explants cultured on MS medium containing $0.01 \mathrm{mg} / \mathrm{L}$ TDZ produced friable, compact, and yellowish calluses (Fig. 1). After a few weeks, several calluses produced multiple shoots. While root explants showed particularly efficient callus and shoot formation, leaf explants did not form shoots. Although TDZ is classified as a type of cytokinin, it is chemically very different from the auxins and cytokinins that are generally used to induce callus and shoot formation, and exerts both auxin- and cytokinin-like effects (Guo et al. 2011). Previous studies have shown that TDZ is much more effective than any other cytokinin for inducing the production of multiple shoots (Bates et al. 1992; Fellman et al. 1987; Neuman et al. 1988; Visser et al. 1992). However, several studies reported that although TDZ induced shoot growth, it did not support continuous shoot elongation (Yoo et al. 1996). In our study, TDZ was more efficient than 2,4-D in triggering callus and shoot formation. The treatment of explants with various concentrations of TDZ showed that high TDZ concentrations induced the formation of larger calli than that by low TDZ concentrations (Fig. 2 and Table 1). However, explants treated with high concentrations of TDZ produced calli that turned yellow in color and stopped growing. In contrast, low TDZ concentrations $(0.01 \mathrm{mg} / \mathrm{L})$ resulted in the formation of multiple shoots. In the case of leaf explants, although TDZ concentrations of 0.5 and 


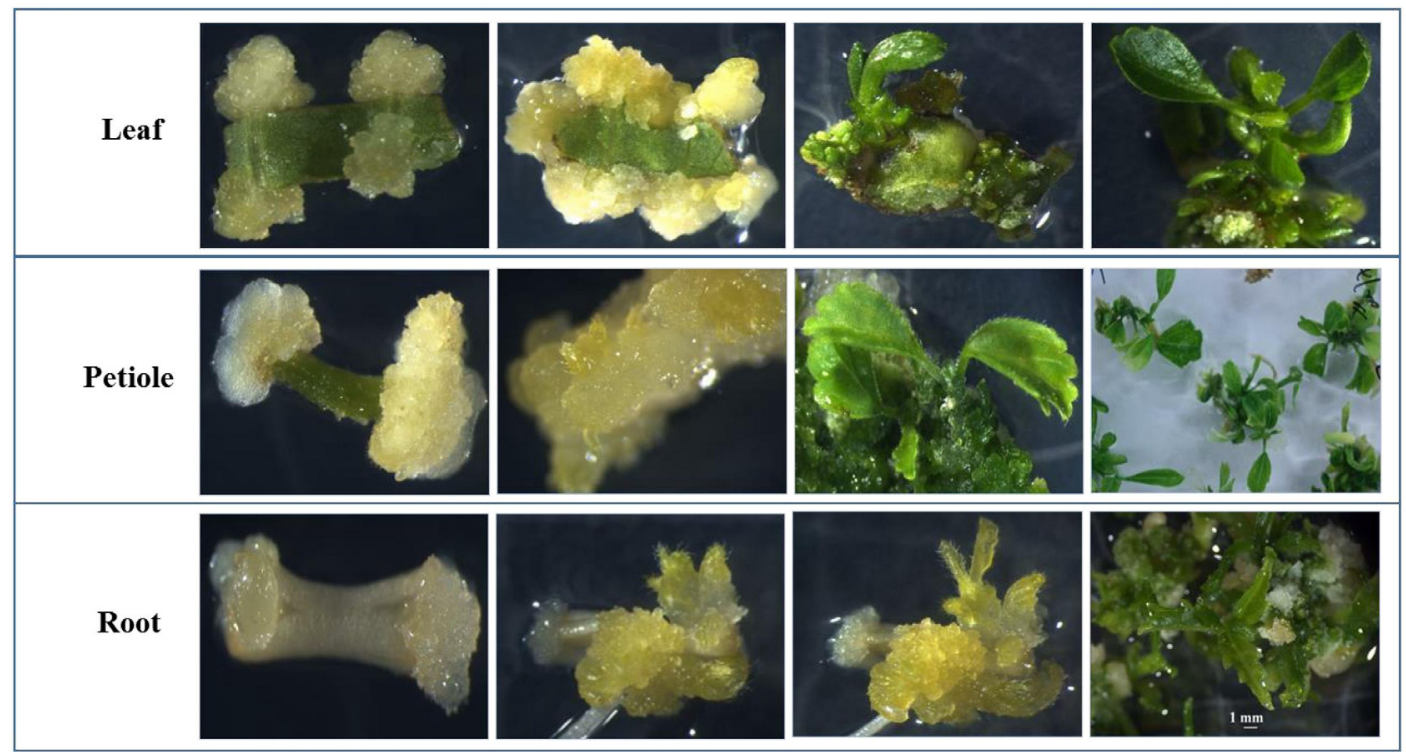

Fig. 1 Plant regeneration in explants derived from various organs of Hibiscus syriacus L. cultured on MS medium containing 0.01 $\mathrm{mg} / \mathrm{L} \mathrm{TDZ}$
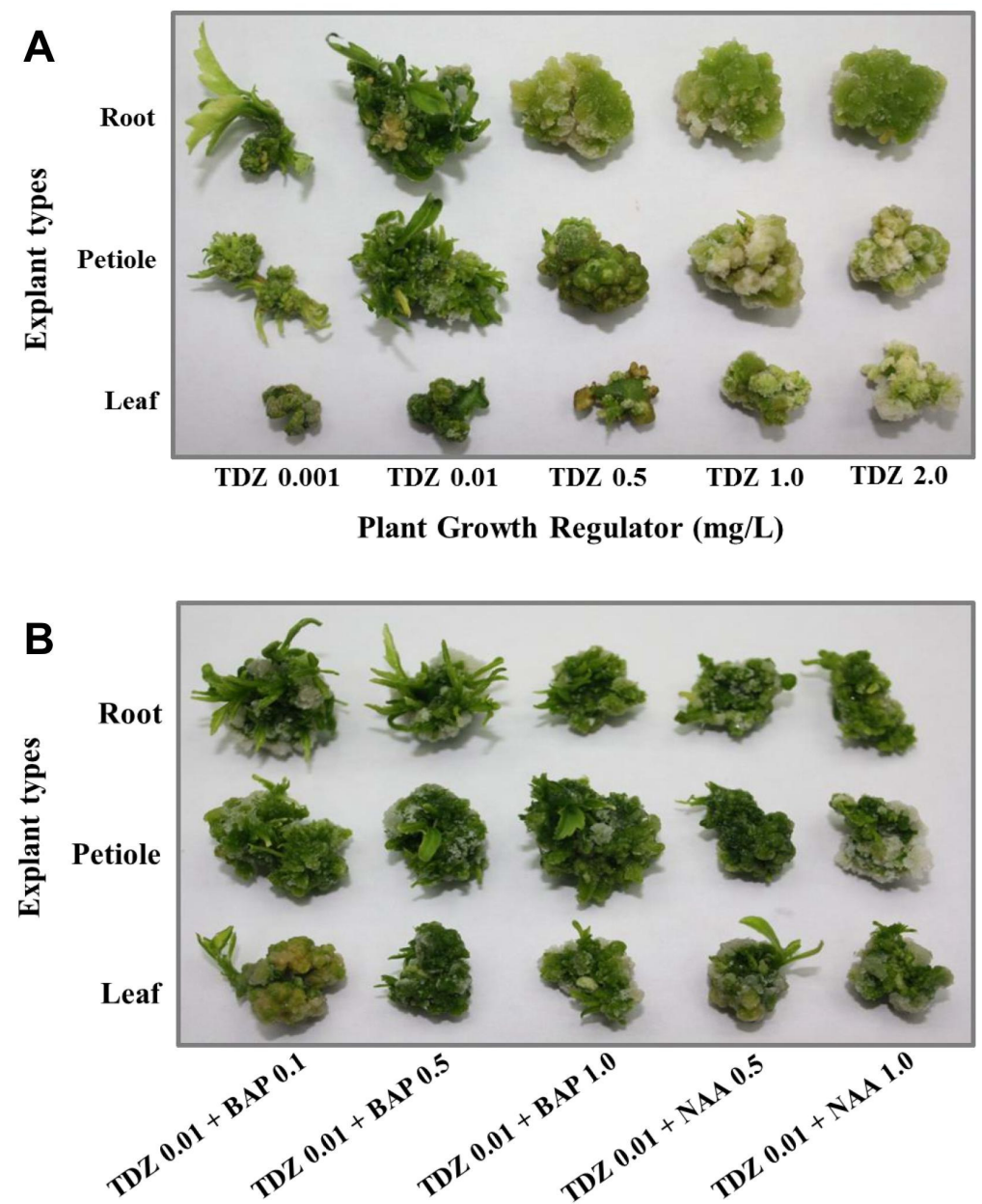

Plant Growth Regulator (mg/L)

Fig. 2 Effects of (A) TDZ concentration and (B) combinations of TDZ with BAP and NAA on callus induction and shoot formation in leaf, petiole, and root explants of Hibiscus syriacusL. 'Saimdang' 
Table 1 Effects of TDZ concentration on callus induction and shoot formation in leaf, petiole, and root explants of Hibiscus syriacus L. 'Saimdang' after 7 weeks of culture

\begin{tabular}{|c|c|c|c|c|}
\hline \multirow{2}{*}{$\begin{array}{l}\text { TDZ concentration } \\
(\mathrm{mg} / \mathrm{L})\end{array}$} & \multicolumn{4}{|c|}{ Leaf } \\
\hline & $\begin{array}{l}\text { Callus formation }{ }^{\mathrm{x}} \\
(\%)\end{array}$ & Callus growth ${ }^{y}$ & $\begin{array}{c}\text { Shoot formation }{ }^{\mathrm{z}} \\
(\%)\end{array}$ & $\begin{array}{l}\text { No. of shoots } \\
\text { /callus }\end{array}$ \\
\hline 0.001 & $25.7 \pm 3.5$ & + & $0.0 \pm 0.0$ & $0.0 \pm 0.0$ \\
\hline 0.01 & $95.1 \pm 3.3$ & + & $0.0 \pm 0.0$ & $0.0 \pm 0.0$ \\
\hline 0.50 & $100.0 \pm 0.0$ & + & $11.2 \pm 2.4$ & $0.2 \pm 0.1$ \\
\hline 1.00 & $100.0 \pm 0.0$ & + & $3.8 \pm 0.5$ & $0.1 \pm 0.0$ \\
\hline \multirow[t]{2}{*}{2.00} & $98.0 \pm 1.0$ & +++ & $0.0 \pm 0.0$ & $0.0 \pm 0.0$ \\
\hline & \multicolumn{4}{|c|}{ Petiole } \\
\hline 0.001 & $58.7 \pm 7.1$ & + & $29.9 \pm 8.6$ & $1.8 \pm 0.7$ \\
\hline 0.01 & $62.5 \pm 7.2$ & +++ & $58.3 \pm 4.2$ & $3.7 \pm 0.7$ \\
\hline 0.50 & $92.9 \pm 4.1$ & ++++ & $17.8 \pm 6.2$ & $0.2 \pm 0.1$ \\
\hline 1.00 & $100.0 \pm 0.0$ & +++ & $15.7 \pm 4.9$ & $0.3 \pm 0.1$ \\
\hline \multirow[t]{2}{*}{2.00} & $100.0 \pm 0.0$ & +++ & $4.0 \pm 2.0$ & $0.1 \pm 0.1$ \\
\hline & \multicolumn{4}{|c|}{ Root } \\
\hline 0.001 & $75.9 \pm 1.3$ & + & $43.2 \pm 13.0$ & $1.1 \pm 0.4$ \\
\hline 0.01 & $98.3 \pm 0.8$ & ++ & $93.2 \pm 0.9$ & $2.9 \pm 0.3$ \\
\hline 0.50 & $100.0 \pm 0.0$ & +++ & $0.0 \pm 0.0$ & $0.0 \pm 0.0$ \\
\hline 1.00 & $97.9 \pm 2.1$ & +++ & $0.0 \pm 0.0$ & $0.0 \pm 0.0$ \\
\hline 2.00 & $93.5 \pm 1.9$ & +++ & $0.0 \pm 0.0$ & $0.0 \pm 0.0$ \\
\hline
\end{tabular}

Each value is the mean \pm SE of 3 replications containing 20 30 explants per replication.

$\mathrm{x} \%$ of explants forming callus per inoculated explant

${ }^{\mathrm{y}}+$ : low; ++: medium; +++: high; ++++ : very high.

$\mathrm{z} \%$ of explants forming shoot per inoculated explant

$1.0 \mathrm{mg} / \mathrm{L}$ were effective for inducing callus formation (Table 1), the calli did not produce shoots. Similarly, 1.0 and $2.0 \mathrm{mg} / \mathrm{L} \mathrm{TDZ}$ concentrations induced callus formation in petiole and root explants (Table 1). However, $0.01 \mathrm{mg} / \mathrm{L}$ TDZ was the most effective concentration for causing shoot formation. At high concentrations, TDZ produced calli in nearly all explants of the Saimdang cultivar. Statistically, both callus formation and shoot formation were the highest at a TDZ concentration of $0.01 \mathrm{mg} / \mathrm{L}$; however, callus formation was completely suppressed at TDZ concentrations higher than $0.01 \mathrm{mg} / \mathrm{L} . \mathrm{TDZ}$ and at low concentrations. Our study showed that by using low levels of TDZ, leaf, petiole, and root explants can be used for in vitro regeneration of $H$. syriacus (Fig. 1).

Effect of Various PGRs on In Vitro Regeneration of $H$. syriacus

Shoot formation was greater in explants or calli cultured on TDZ media when low concentrations of auxins and cytokinins are added to the medium and shoot proliferation increased significantly (Huetteman and Preece 1993). Although BAP is considered the most effective cytokinin, its effectiveness is restricted to certain explant types (Tiwari et al. 2001). Kumari and Pandey (2011) reported that BAP, in combination with IAA, was the most effective cytokinin for shoot differentiation. However, high concentrations of BAP $(2.0 \mathrm{mg} / \mathrm{L})$ may inhibit growth by up to $81 \%$ of the shoots formed from the axillary buds of in vitro-germinated seedlings of $H$. sabdariffa $\mathrm{L}$. treated with hormone-free medium, and only $33 \%$ shoot formation was recorded for seedlings treated with high concentrations of BAP (GovindenSoulange et al. 2009). After 7 weeks of culture, treatment of explants with combinations of TDZ, BAP, and NAA showed that callus formation was the highest and shoot formation was the lowest at an NAA concentration of 0.5 $\mathrm{mg} / \mathrm{L}$ (Table 2). The addition of $1.0 \mathrm{mg} / \mathrm{L}$ of BAP to the medium resulted in the highest shoot formation in leaf and petiole explants (Table 2), and the addition of $0.1 \mathrm{mg} / \mathrm{L}$ BAP resulted in higher shoot formation in root explants (Table 2). Overall, adding BAP to the medium enhanced shoot induction and formation in calluses with multiple 
Table 2 Effects of combination of TDZ with various concentrations of plant growth regulators (BAP and NAA) on callus induction and shoot formation in leaf, petiole, and root explants of Hibiscus syriacus L. 'Saimdang' after 7 weeks of culture

\begin{tabular}{|c|c|c|c|c|c|}
\hline \multicolumn{2}{|c|}{$\begin{array}{l}\text { Plant growth regulator } \\
\text { TDZ } 0.01 \mathrm{mg} / \mathrm{L} \text { with }\end{array}$} & \multicolumn{4}{|c|}{ Leaf } \\
\hline $\begin{array}{l}\text { BAP } \\
(\mathrm{mg} / \mathrm{L})\end{array}$ & $\begin{array}{l}\mathrm{NAA} \\
(\mathrm{mg} / \mathrm{L})\end{array}$ & $\begin{array}{l}\text { Callus formation }{ }^{\mathrm{x}} \\
(\%)\end{array}$ & Callus growth ${ }^{\mathrm{y}}$ & $\begin{array}{l}\text { Shoot formation }{ }^{\mathrm{z}} \\
(\%)\end{array}$ & $\begin{array}{l}\text { No. of shoots } \\
\text { /callus }\end{array}$ \\
\hline 0.10 & 0.00 & $89.9 \pm 2.2$ & ++ & $32.4 \pm 8.2$ & $0.7 \pm 0.1$ \\
\hline 0.50 & 0.00 & $94.4 \pm 2.6$ & ++ & $16.0 \pm 6.2$ & $0.3 \pm 0.1$ \\
\hline 1.00 & 0.00 & $86.1 \pm 4.9$ & ++ & $50.2 \pm 2.6$ & $1.8 \pm 0.1$ \\
\hline 0.00 & 0.50 & $100.0 \pm 0.0$ & ++ & $21.5 \pm 11.1$ & $0.3 \pm 0.2$ \\
\hline \multirow[t]{2}{*}{0.00} & 1.00 & $98.9 \pm 1.1$ & +++ & $8.0 \pm 4.0$ & $0.1 \pm 0.1$ \\
\hline & & \multicolumn{4}{|c|}{ Petiole } \\
\hline 0.10 & 0.00 & $69.2 \pm 4.7$ & +++ & $49.3 \pm 10.0$ & $2.5 \pm 0.6$ \\
\hline 0.50 & 0.00 & $93.7 \pm 6.3$ & +++ & $77.3 \pm 4.6$ & $1.7 \pm 0.2$ \\
\hline 1.00 & 0.00 & $98.2 \pm 1.8$ & +++ & $92.3 \pm 1.4$ & $3.3 \pm 0.5$ \\
\hline 0.00 & 0.50 & $100.0 \pm 0.0$ & +++ & $22.1 \pm 3.8$ & $0.4 \pm 0.1$ \\
\hline \multirow[t]{2}{*}{0.00} & 1.00 & $95.6 \pm 2.2$ & +++ & $33.3 \pm 5.4$ & $0.3 \pm 0.2$ \\
\hline & & \multicolumn{4}{|c|}{ Root } \\
\hline 0.10 & 0.00 & $100.0 \pm 0.0$ & ++ & $98.5 \pm 1.5$ & $3.6 \pm 0.5$ \\
\hline 0.50 & 0.00 & $98.3 \pm 0.9$ & ++ & $73.6 \pm 12.0$ & $1.9 \pm 0.6$ \\
\hline 1.00 & 0.00 & $95.6 \pm 2.2$ & ++ & $86.6 \pm 1.4$ & $2.5 \pm 0.1$ \\
\hline 0.00 & 0.50 & $100.0 \pm 0.0$ & ++ & $54.7 \pm 4.3$ & $0.9 \pm 0.2$ \\
\hline 0.00 & 1.00 & $100.0 \pm 0.0$ & +++ & $41.4 \pm 12.0$ & $0.7 \pm 0.2$ \\
\hline
\end{tabular}

Each value is the mean \pm SE of 3 replications containing $25 \sim 35$ explants per replication.

$\mathrm{x} \%$ of explants forming callus per inoculated explant

y +: low; ++: medium; +++: high; ++++: very high.

$\mathrm{z} \%$ of explants forming shoot per inoculated explant

Table 3 Effects of IAA concentration on rooting in micro shoots of Hibiscus syriacus L. 'Saimdang'

\begin{tabular}{cc}
\hline $\begin{array}{c}\text { IAA concentration } \\
(\mathrm{mg} / \mathrm{L})\end{array}$ & Root emergence $^{\mathrm{x}}$ (days) \\
\hline 0.00 & $21.3 \pm 0.8$ \\
0.01 & $21.8 \pm 0.8$ \\
0.10 & $19.8 \pm 0.5$ \\
0.50 & $21.0 \pm 1.7$ \\
1.00 & $18.6 \pm 0.6$ \\
1.50 & $20.8 \pm 2.1$ \\
\hline
\end{tabular}

Each value is the mean \pm SE of 3 replications containing 5 micro shoots per replication. Experiment was repeated three times. ${ }^{\mathrm{x}}$ number of days required for root emergence from micro shoot.

shoots were induced in green calli treated with $0.01 \mathrm{mg} / \mathrm{L}$ TDZ and either 0.1 or $1.0 \mathrm{mg} / \mathrm{L}$ BAP.

Rooting and Acclimation of in vitro Regenerated Plants

Six concentrations of IAA were compared for their efficiency in inducing in vitro root formation. Up to $20 \%$ of the enlarged shoots developed roots on basal media without PGRs
(Table 3). Our results show that rooting in H. syriacus, which typically requires 1 month, was completely dependent on exogenous auxin. Excised axillary nodes, derived from in vitro-cultured shoots, formed roots only upon transfer to hormone-free half-strength MS medium or half-strength MS medium supplemented with different concentrations of IAAs. In vitro rooting of initiated shoots occurred after 
approximately 18.5 days of culture on half-strength MS basal medium containing $1.0 \mathrm{mg} / \mathrm{L}$ IAA (Table 3). A single root emerged after 18 days, continued to grow linearly, and produced branches. Root emergence in media containing all other concentrations of IAA (excluding 1.0 $\mathrm{mg} / \mathrm{L}$ ) was delayed by 1-3 days (Table 3 ).

In conclusion, an efficient in vitro plant propagation protocol for rapid multiplication was established for $H$. syriacus. Efficient in vitro plant regeneration methods are essential improving the mass production and molecular manipulation of plants. Thus, the protocol developed in this study shows potential for use in further research to manipulate and propagate $H$. syriacus, as well as for eventual application in the horticulture industry.

\section{Acknowledgments}

This work was supported by the 2014 sabbatical year research grant of the University of Seoul.

\section{References}

Bates S, Navarrete JE, Sammbeek JW, Gaffney GR (1992) Thidiazuron stimulates shoot organogenesis and somatic embryogenesis in white ash (Fraxinus americana L). Plant Cell Tissue Organ Cult 32:21-29

Cui J, Chen JJ, Henny RJ (2009) Regeneration of Aeschynanthusradicans via direct somatic embryogenesis and analysis of regenerants with flow cytometry. In Vitro Cell Dev Biol Plant 45:34-43

Fellman CD, Read PE, Hosier MA (1987) Effects of thidiazuron and CPPU on meristem formation and shoot proliferation. HortScience 22:1197-1200

Govinden-Soulange J, Boodia N, Dussooa C, Gunowa R, Deensah S, Facknath S, Rajkomar B (2009) Vegetative propagation and tissue culture regeneration of Hibiscus sabdariffa L(Roselle). World J Agric Sci 5:651-661

Guo B, Abbasi BH, Zeb A, Xu LL, Wei YH(2011) Thidiazuron: A multi-dimensional plant growth regulator. Afr J Biotechnol 10:8984-9000

Hartman BH, Kester DE, Davies FT (1994) Plant propagation: principles and techniques. p. 246-247. Prentice Hall, New Jersey.

Hotta M, Ogata K, Nitta A, Hosikawa K, Yanagi M,Yamazaki K (1989) Useful plants of the world. p. 1499. Heibonsha, Tokyo, Japan

Huetteman CA, Preece JE (1993) Thidiazuron: a potent cytokinin for woody plant tissue culture. Plant Cell Tissue Organ Cult 33:105-119

Hutchinson MJ, Murch SJ, Saxena PK (1996) Morphoregulatory role of thidiazur on: evidence of the involvement of endogenous auxin in thidiazuron-induced somatic embryogenesis of geranium (Pelargonium $\times$ hortorum Bailey). J plant physiol 149:573-579

Jeon SB, Kang SW, Kim WS, Lee GP, Kim SH, Seo SG (2009) In vitro plant regeneration from axillary buds of Hibiscus syriacus L. J Plant Biotechnol 36:174-178

Jones MPA, Cao J, O’Brien R, Murch SJ, Saxena PK (2007) The mode of action of thidiazuron: auxins, indoleamines, and ion channels in the regeneration of Echinacea purpurea L. Plant Cell Rep 26:1481-1490

Kim EK, Yoo YK, Kim KS (1998) Effect of thidiazuron on callus and multiple shoot formation in shoot-tip culture of Hibiscus syriacus L. 'Honghwarang'. Kor J Hort Sci Technol 16:520-524

Kumari, S. and R.K. Pandey (2011) In vitro plant regeneration form shoot tip explants of Hibiscus syriacus (L.). Int Q J Life Sci 6:647-648

Lo KH, Giles KL, Sawhney VK (1997) Acquisition of competence for shoot regeneration in leaf discs of Saintpaulia ionantha $\mathrm{x}$ confusa hybrids (African violet) cultured in vitro. Plant Cell Rep 16: 416-420

Ma GH, Lu J, Teixeira da Silva JA, Zhang X, Zhao J (2011) Shoot organogenesis and somatic embryogenesis from leaf and shoot explants of Ochna integerrima (Lour). Plant Cell Tissue Organ Cult 104:157-162

Mithila J, Hall JC, Victor JMR, Saxena PK (2003) Thidiazuron induces shoot organogenesis at low concentrations and somatic embryogenesis at high concentrations on leaf and petiole explants of African violet (Saintpaulia Ionantha Wendl.). Plant Cell Rep 21:408-414

Murashige T, Skoog F (1962) A revised medium for rapid growth and bioassays with tobacco tissue cultures. Physiol Plant 15:473-497

Murch SJ, Saxena PK (2001) Molecular fate of thidiazuron and its effects on auxin transport in hypocotyls tissues of Pelargonium $\times$ hortorum Bailey. Plant Growth Regul 35:269-275

Murthy BNS, Murch SJ, Saxena PK (1998) Thidiazuron: A potent regulator ofin vitro plant morphogenesis. In Vitro Cellular \& Developmental Biology-Plant 34:267

Neuman MC, Preece JE, Gaffney GR, VANSAMBEEK JW (1988) Production of embryoid-like structures from immature cotyledonary tissue of black walnut (Juglansnigra L). HortScience 23:807

Peak KY, Son YJ, Hwang JK, Jong SK, Park SI (1989) Plant regeneration in tissue culture initiated from immature embryos of Hibiscus syriacus L. Korean J Plant Tissue Cult 16:93-104

Taha RM, Daud N, Hasbullah NA, Awal A (2009) Somatic embryogenesis and production of artificial seeds in Saintapaulia ionantha Wendl. Acta Hortic 829:331-336

Takagi H, Sugawara S, Saito T, Tasaki H, Yuanxue L, Kaiyun G, Han D-S, Godo T, Nakano M (2011) Plant regeneration via direct and indirect adventitious shoot formation and chromosomedoubled somaclonal variation in Titanotrichum oldhamii (Hemsl.) Solereder. Plant Biotechnol Rep 5:187-195

Tiwari V, Tiwari KN, Singh BD (2001) Comparative studies of cytokinins on in vitro propagation of Bacopamonniera. Plant 
Cell Tissue Organ Cult 66:9-16

Visser C, Qureshi JA, Gill R, Saxena PK (1992) Morphoregulatory role of TDZ. Substitution of auxin and cytokinin requirement for the induction of somatic embryogenesis in geranium hypocotyl culture. Plant Physiol 99:1704-1707

Yoo EH, YooYK, Kim KS (1996) Effects of growth regulators, sucrose, light, and medium on callus and shoot formation in shoot-tip culture of Hibiscus syriacus L. 'Honghwarang'. J Kor Soc Hort Sci 37:317-323

Zhao YX, Yao DY, Harris PJC (1991) Isolation and culture of protoplasts from callus tissue of Hibiscus syriacus L. Plant Cell Tissue Organ Cult 25:17-19 